\title{
Nutritional Evaluation of Garden Cress Chikki
}

\author{
Tanu Jain* and Kiran Grover \\ Department of Food and Nutrition, Punjab Agricultural University, India
}

Submission: January 23, 2017; Published: February 21, 2017

"Corresponding author: Tanu Jain, Department of Food and Nutrition, College of Home Science, Punjab Agricultural University, Ludhiana, Punjab, India Email: jain.tanu25@gmail.com

\begin{abstract}
Background: Chikki is a popular traditional sweet snack of India. It can be made nutrient dense with the supplementation of garden cress seeds which contain a remarkable percent of protein, fat, energy, minerals and vitamins. The present study aimed to perform nutritional evaluation of the nutrient rich garden cress chikki.
\end{abstract}

Materials and methods: Roasted garden cress seeds were supplemented in chikki at the level of 25 percent to make it nutrient dense and nutritional evaluation of control and supplemented chikki was performed to analyze their proximate composition, amino acids, fatty acid composition, minerals, in-vitro starch and protein digestibility and anti nutritional factors.

Results and discussion: The supplemented chikki contained significantly $(\mathrm{p} \leq 0.01)$ higher percentage of protein $(14.47 \%)$, fat $(21 \%)$, ash (4.5\%), fibre $(2.90 \%)$ and energy ( $482 \mathrm{Kcal} / 100 \mathrm{~g}$ ) than control chikki. amino acids content and fatty acid composition were also found to be increased in garden cress chikki as compared to control chikki. It also provided significantly ( $\mathrm{p} \leq 0.01)$ improved amount of calcium (163.57 $\mathrm{mg} / 100 \mathrm{~g})$, iron $(9.92 \mathrm{mg} / 100 \mathrm{~g})$, and zinc $(2.24 \mathrm{mg} / 100 \mathrm{~g})$ with increased per cent ionizable iron $(11.97 \%)$ and its per cent bioavailability (6.11\%). The supplemented chikki was found with increased oxalates $(73.88 \mathrm{mg} / 100 \mathrm{~g})$ and phytin phosphorus content (286.1 mg / $100 \mathrm{~g})$ which decreased the in vitro digestibility of starch (57.92\%) and protein (82.27\%) in supplemented chikki.

Conclusion: Roasted garden cress seeds supplemented chikki was found richer in proximate, amino acids and fatty acid composition than control chikki which has potential to be fed to poor and malnourished children through various supplementary feeding programmers.

Keywords: Chikki; Garden cress; Nutritional evaluation; Traditional snack

\section{Introduction}

Chikki is a popular traditional sweet snack of India which is likes and consumed by all the sections of population. It is formulated with roasted peanuts and jaggery syrup which provides calories, protein and other nutrients. The nutritional value of Chikki can be enhanced with the supplementation of garden cress seeds. Garden cress (Lepidiumsativum, familyCruciferae) has been considered as an important nutritional and medicinal plant in India since Vedic era due to its health promoting properties. The seeds contain 25.3 per cent protein 24.5 per cent fat and provide $454 \mathrm{Kcal} / 100 \mathrm{~g}$. It is a good source of calcium $(377 \mathrm{mg} / 100 \mathrm{~g})$, iron $(100 \mathrm{mg} / 100 \mathrm{~g})$, magnesium $(430 \mathrm{mg} / 100 \mathrm{~g}$ ) and other nutrients (thiamine, $0.59 \mathrm{mg} / 100 \mathrm{~g}$; riboflavin, 0.61mg/100g; niacin, $14.3 \mathrm{mg} / 100 \mathrm{~g}$ ) Gopalan et al. [1]. It also acts as memory boosters as it contains essential fatty acids like arachidic and linoleic acid. It is commonly known as "common cress", "land cress", "Haliv", "Asalio" or "Chandrasur" in India Gokavi et al. [2]. It is specifically a winter crop but grown in all seasons in every parts of India.
So an attempt has been made to develop nutrient rich garden cress chikki and analyze its nutrient composition over control chikki. Being cost effective, it may help to improve nutritional status and reduce malnutrition.

\section{Material and methods}

\section{Procurement or garden cress seeds}

Garden cress seeds, used for the preparation of food products, were purchased from local market. The seeds were roasted (at $150^{\circ} \mathrm{C}$ approximately for 3-5 minutes) in an iron vessel till a prominent aroma of garden cress seeds comes. After cooling, the seeds were packed in air tight plastic container and stored at ambient conditions $\left(20^{\circ} \mathrm{C}, 60 \% \mathrm{RH}\right)$.

\section{Preparation of chikki}

Preparation of chikki was done in the Food Laboratory of Food and Nutrition Department, College of Home Science, PAU, Ludhiana. Chikki were developed by using the following 
formulations: Jaggery $(80 \mathrm{~g})$ was crushed and made into syrup with addition of water $(40 \mathrm{ml})$ by heating it till the temperature reached $145^{\circ} \mathrm{C}$ and immediately roasted peanut halves was added after turning off the flame and mixed thoroughly till peanuts get coated with jaggery syrup. The mixture was poured on a pre greased surface and spread uniformly with the help of roller, cut into square pieces and kept for cooling at room temperature [3].

Garden cress chikki was developed by supplementing 25 percent of roasted garden cress seeds which was found organoleptically acceptable among all treatment (15,20,25\% level of supplementation) on the 9 point hedonic scale [4] by the panel of 10 judges who were familiar with the major sensory attributes of food products.

\section{Nutritional Analysis}

\section{Proximate composition}

Proximate composition was analyzed by standard methods [5].

Amino acid analysis: Extraction of sulphur amino acids was done by hydrolysing the samples in autoclave for 6 hours at $15 \mathrm{lb}$ pressure. After filtration, hydrolyzed samples were used for the determination of methionine [6] and cystine [7]. Lysine was assessed by method of Carpenter, 1960 modified by Booth, 1971 and estimation of tryptophan was done by Concon [8].

\section{Estimation of fatty acid composition}

Oil was extracted from raw and processed garden cress powder through soxhlet extraction method and extracted oil samples were analyzed for fatty acid composition by gas chromatography using fatty acid methyl esters (FAME) preparation [9]. FAMEs were analyzed on a gas chromatograph (Varian CP 3800, USA), equipped with a flame ionization detector (FID) and a fused silica capillary column ( $50 \mathrm{~m} \times 0.25 \mathrm{~mm}$ i.d.), coated with CP-SIL 88 as the stationary phase. The oven temperature was set at $200^{\circ} \mathrm{C}$ for $13 \mathrm{~min}$. The injector and FID were at $250^{\circ} \mathrm{C}$. A reference standard FAME mix (Supelco Inc.) was analysed under the same operating conditions to determine the peak identity. The samples were analysed for saturated fatty acids (C 16:0 and C 18:0), mono unsaturated fatty acids (C 18:1 and C 20:1) and poly unsaturated fatty acids (C 18:2 and C 18:3). The FAMEs were expressed as relative area percentage.

\section{Total minerals}

For minerals, the samples were wet digested in hot plate using nitric acid and perchloric acid mixture in 5:1 ratio (v/v) and used for the determination of total amount of calcium, iron and zinc by atomic absorption spectrophotometry [10].

Percent ionizable iron and percent iron bioavailability: In vitro iron was performed by following [11] method and percent bioavailability was estimated by using the following equation defined by Rao \& prabhawati [11].

$$
\begin{aligned}
& \mathrm{Y}=0.4827+0.4707 \mathrm{X} \\
& \mathrm{X}=\frac{\text { Ionizable iron }}{\text { Total iron }} \times 100 \\
& \text { where, } \mathrm{Y}=\% \text { iron absorption in adult } \\
& \mathrm{X}=\text { ionizable iron at } \mathrm{pH} 7.5
\end{aligned}
$$

In vitro starch, protein and iron: In vitro digestibility of carbohydrate was performed by estimating the quantity of maltose released from samples by employing dinitrosalicylic acid method of Bernfeld [12]. For digestion of starch, pancreatic alpha amylase was used and samples were incubated at $37^{\circ} \mathrm{C}$ for two hours. Amount of released maltose was expressed in percentage. In vitro protein digestibility was assessed by Akeson \& stachman [13] method. The samples were digested with pepsin solution followed by pancreatin solution and incubated at $37^{\circ} \mathrm{C}$ for 24 hours. The amount of nitrogen from the digested samples was calculated by subtracting residual protein from total protein of the sample and expressed in percentage.

$$
\text { Protein digestibility }(\%)=\frac{(\text { Total Protein }- \text { residual protein })}{\text { Total Protein }} \times 100
$$

\section{Antinutritional factors}

Oxalic acid was determined by titring oxalates containing sulphuric acid against potassium permanganate as described by Abeza et al. [14] and extraction of phytic acid was done by employing hydrochloric acid and keeping the solution for 3 hours. Amount of phytin phosphorus was measured by using 2, 2 bipyridine solution on spectrophotometer [15].

\section{Statistical analysis}

The values were taken in triplicate and data were subjected to statistical analysis using Statistical Package for Social Sciences (SPS) version 16.0. t test was used to obtain the differences between control and garden cress seeds supplemented chikki. Level of significance was accepted at $\mathrm{p}<$ 0.05 .

\section{Nutritional evaluation}

Table 1: Proximate composition of control and garden cress chikki.

\begin{tabular}{|c|c|c|c|}
\hline $\begin{array}{c}\text { Proximate } \\
\text { Composition } \\
(\%)\end{array}$ & Control & Acceptable & T Test \\
\hline Protein & $13.83 \pm 0.08$ & $14.47 \pm 0.35$ & $3.87^{* *}$ \\
\hline Fat & $20.24 \pm 0.15$ & $21.00 \pm 0.15$ & $11.83^{* *}$ \\
\hline Fiber & $2.22 \pm 0.15$ & $2.90 \pm 0.10$ & $7.9^{* *}$ \\
\hline Ash & $4.1 \pm 0.1$ & $4.5 \pm 0.1$ & $5.94^{*}$ \\
\hline Cardohydrate & 59.61 & 57.13 & - \\
\hline Energy (Kcal) & 471.57 & 482.03 & - \\
\hline
\end{tabular}

\#Carbohydrate=100-(Protein+Fat+Fiber+Ash)

$@$ Energy $=($ Protein $\times 4)+($ Carbohydrate $\times 4)+($ Fat $\times 9)$

Acceptable level of garden cress supplementation at $25 \%$ 
Values are mean \pm SD

*Significant at $5 \%$ level

**Significant at $1 \%$ level.

Proximate composition: The perusal of the Table 1 showed the proximate composition of control and supplemented chikki. The protein content of chikki was analyzed as $13.83 \pm$ 0.08 per cent in control chikki which was higher by 4.47 per cent in supplemented chikki $(14 \pm 0.17 \%)$ with significant difference $(\mathrm{p} \leq 0.01)$. The fat content of supplemented chikki $(21.46 \pm 0.15 \%)$ was significantly ( $\mathrm{p} \leq 0.01)$ increased $(5.72$ $\%)$ with supplementation of garden cress seeds as compared to control (20.24 $\pm 0.15 \%)$. Similarly, fibre content also found to be increased significantly in supplemented chikki $(2.90 \pm 0.10 \%)$. The ash content of control chikki was found to be $4.1 \pm 0.10$ per cent which increased (9.76\%) significantly to $4.5 \pm 0.10$ per cent in supplemented chikki. The available carbohydrate and energy content of control and supplemented chikki was calculated as 59.61 and 57.13 per cent and 471.57 and 482.03 Kcal respectively. Chahal \& Sehgal [16] and Byrappa et al. [17] prepared chikki using till and ground nut and soy protein isolate, which supports the results of present study.

\section{Amino acids}

Table 2: Amino acid and fatty acid composition of control and garden cress chikki

\begin{tabular}{|c|c|c|c|}
\hline Amino Acids (g/100g of protein) & Control & Acceptable & t test \\
\hline Methionine & $0.93 \pm 0.03$ & $0.95 \pm 0.05$ & $0.62 *$ \\
\hline Lysine & $3.58 \pm 0.03$ & $4.01 \pm 0.06$ & $4.2^{* *}$ \\
\hline Tryptophan & $0.93 \pm 0.08$ & $1.11 \pm 0.07$ & 1.96 \\
\hline Cystine & $1.19 \pm 0.04$ & $1.13 \pm 0.02$ & 1.21 \\
\hline \multicolumn{4}{|c|}{ Fatty Acid Composition (\%) } \\
\hline Palmitic acid (16:0) & $12.63 \pm 2.20$ & $12.33 \pm 2.00$ & 0.87 \\
\hline Stearic acid (18:0) & $2.87 \pm 0.15$ & $2.90 \pm 0.20$ & 0.91 \\
\hline Oleic acid (18:1) & $41.20 \pm 2.08$ & $41.83 \pm 1.35$ & 1.08 \\
\hline Linoleic acid (18:2) & $34.03 \pm 0.21$ & $34.07 \pm 0.23$ & 0.88 \\
\hline Linolenic acid (18:3) & $0.60 \pm 0.10$ & $1.20 \pm 0.10$ & $8.82^{* *}$ \\
\hline Ecosanoic acid (20:1) & $1.63 \pm 0.05$ & $1.62 \pm 0.06$ & 0.74 \\
\hline
\end{tabular}

Acceptable level of garden cress supplementation at $25 \%$

Values are mean \pm SD

*Significant at $5 \%$ level

**Significant at $1 \%$ level.

Amino acid content of chikki has been tabulated in the Table 2. The lysine content of supplemented chikki (4.01 \pm $0.06 \mathrm{~g} / 100 \mathrm{~g}$ protein) was found to be significantly ( $\mathrm{p} \leq 0.01)$ increased by 12.0 per cent as compared to control $(3.58 \pm 0.03$ g per 100 g protein). Peanuts have less lysine (3.58g /100 g protein) content, which was replaced by roasted garden cress seeds which has more lysine $(5.90 \mathrm{~g} / 100$ gprotein) $[1,18]$. The methionine content of supplemented chikki 0.95 $\pm 0.05 \mathrm{~g} / 100 \mathrm{~g}$ protein) was found to be increased than that of control $(0.93 \pm 0.03 \mathrm{~g} / 100 \mathrm{~g}$ protein $)$ due to garden cress supplementation which has more methionine content $(0.97 \mathrm{~g} / 100 \mathrm{~g}$ protein) than peanuts $(0.93 \mathrm{~g} / 100 \mathrm{~g}$ protein $)$. The cystine content for control was analyzed as $1.19 \pm 0.04$ g per $100 \mathrm{~g}$ protein while for supplemented chikki it was observed to be $1.13 \pm 0.02$ per 100 g protein. The tryptophan content for control and supplemented chikki was found to be $0.93 \pm 0.08$ and $1.01 \pm 0.07$ g per 100 g protein (Table 2). Garden cress seeds have good amount of lysine and fair amount of tryptophan but limited in methionine and cystine content. Thus value of methionine was decreased in supplemented chikki.

\section{Fatty acid composition}

Chikki showed $12.63 \pm 2.20,41.2 \pm 2.08,34.03 \pm 0.21$ per cent palmitic, oleic and linoleic acid (Table 2). But supplemented chikki showed a little decrease in palmitic $(12.33 \pm 2.0 \%)$ and a little increase in oleic (41.83 \pm 1.35 $\%)$ and linoleic acid content (34.07 $\pm 0.23 \%$ ). Linolenic acid increased significantly ( $\mathrm{p} \leq 0.01$ ) from $0.60 \pm 0.10$ per cent to $1.20 \pm 0.10$ per cent in supplemented chikki. Almost negligible difference was found in stearic $(2.87 \pm 0.15$ and $2.90 \pm 0.20$ $\%$ in control and supplemented chikki) and ecosanoic acid content $(1.63 \pm 0.05 \%$ and $1.62 \pm 0.06 \%$ in control and supplemented chikki). The results are in line with the study reported by Chetana \& Sunkireddy [3] in which groundnut was substituted with flex seeds which significantly increased $\omega 3$ fatty acid content.

Garden cress is rich in linolenic acid. Thus, it increased almost half to double in amount in all food preparation with addition of cress seeds. Value addition with incorporation of garden cress seeds (Lepidiumsativum), green gram dhal (Phaseolus aureus Roxb.) or linseed (Linumusitatissimum) 
increased $\omega 3$ fatty $116 \mathrm{mg}$ per $100 \mathrm{~g}$ in the value added flakes [19]. Being rich in unsaturated fatty acids, garden cress seeds provide a good option to balance the polyunsaturated: saturated fatty acid ratio as well as to increase linolenic acid content in diet through supplemented chikki.

\section{Mineral content}

A significant $(p \leq 0.01)$ increase of 61.83 per cent was found in case of control chikki (6.13 $\pm 0.12 \mathrm{mg} / 100 \mathrm{~g}$ ) with addition of roasted garden cress seeds in supplemented chikki (9.92 $\pm 0.16 \mathrm{mg} / 100 \mathrm{~g})$. But per cent ionizable iron increased from 11.77 (control) to 11.97 per cent (supplemented), only which might be due to increase in fibre and phytate content of seeds which inhibited the in vitro iron digestibility of product (Table 3). The calculated per cent iron bioavailability was 6.02 and 6.11 for the control and supplemented chikki. Chahal \& Sehgal [16] also showed increase in iron content of groundnut chikki on addition of till in it.

Table 3: Mineral content and In vitro digestibility of control and garden cress chikki

\begin{tabular}{|c|c|c|c|}
\hline $\begin{array}{c}\text { Minerals (mg } \\
\text { /100 g) }\end{array}$ & Control & Acceptable & t test \\
\hline Iron & $6.13 \pm 0.12$ & $9.92 \pm 0.16$ & $39.09^{* *}$ \\
\hline $\begin{array}{c}\text { Percent } \\
\text { ionisable iron }\end{array}$ & 11.77 & 11.97 & \\
\hline $\begin{array}{c}\text { Percent iron } \\
\text { bioavailability }\end{array}$ & 6.02 & 6.11 & $28.91^{* *}$ \\
\hline $\begin{array}{c}\text { Calcium } \\
\text { Zinc }\end{array}$ & $124 \pm 2.69$ & $\begin{array}{c}163.57 \pm \\
0.85\end{array}$ & $2.83^{*}$ \\
\hline $\begin{array}{c}\text { In vitro } \\
\text { digestibility } \\
\text { (\%) }\end{array}$ & $2.21 \pm 0.02$ & $2.24 \pm 0.01$ & $7.40^{* *}$ \\
\hline $\begin{array}{c}\text { In vitro starch } \\
\text { digestibility }\end{array}$ & $58.53 \pm$ & $57.92 \pm$ \\
\hline $\begin{array}{c}\text { In vitro } \\
\text { protein } \\
\text { digestibility }\end{array}$ & $83.57 \pm 0.6$ & $82.27 \pm$ & 0.25 \\
\hline Acceptable level & 9.68 & $2.22^{*}$ \\
\hline
\end{tabular}

Acceptable level of garden cress supplementation at $25 \%$

Values are mean \pm SD

*Significant at $5 \%$ level

**Significant at $1 \%$ level.

The calcium content $(124 \pm 2.69 \mathrm{mg} / 100 \mathrm{~g})$ of chikki increased significantly ( $\mathrm{p} \leq 0.01)$ to $163.57 \pm 0.85 \mathrm{mg}$ per 100 g with supplementation (Table 3). Chahal \& Sehgal [16] also showed increased calcium content in till groundnut chikki as compared to groundnut chikki. Nathiya \& Vigasini [20] also reported improved calcium content of garden cress seeds incorporated nutricookies.

Control chikki was found with $2.21 \pm 0.02 \mathrm{mg}$ per $100 \mathrm{~g}$ of zinc content while the value significantly $(\mathrm{p} \leq 0.05)$ increased to $2.24 \pm 0.01 \mathrm{mg}$ per $100 \mathrm{~g}$ in supplemented chikki. Similar results were reported in study of Chahal \& Sehgal [16] who prepared groundnut chikki by partially substituted with till.

\section{In vitro digestibility}

The perusal of the data in the Table 3 revealed that values for control and supplemented chikki was found to be $58.53 \pm$ 0.68 and $57.92 \pm 0.54$ per cent for in vitro starch digestibility and $83.57 \pm 0.60$ and $82.27 \pm 0.25$ per cent for in vitro protein digestibility with significant $(\mathrm{p} \leq 0.01$ ) difference for both parameters. It may be inferred that in vitro digestibility for starch and protein was found to be decreased with the addition of garden cress seeds supplementation due to its high fibre content.

\section{Antinutritional factors}

Table 4: Antinutritional factors of control and garden cress chikki

\begin{tabular}{|c|c|c|c|}
\hline $\begin{array}{c}\text { Anti } \\
\text { Nutritional } \\
\text { Factors } \\
\text { (mg / 100 } \\
\text { g) }\end{array}$ & Control & Acceptable & t test \\
\hline Oxalates & $72.9 \pm 0.36$ & $\begin{array}{c}73.88 \pm \\
0.47\end{array}$ & 1.15 \\
\hline $\begin{array}{c}\text { Phytin } \\
\text { phosphorus }\end{array}$ & $\begin{array}{c}284.8 \pm \\
2.26\end{array}$ & $\begin{array}{c}286.1 \pm \\
2.46\end{array}$ & 1.3 \\
\hline
\end{tabular}

Acceptable level of garden cress supplementation at $25 \%$

Values are mean \pm SD

*Significant at $5 \%$ level

${ }^{* *}$ Significant at $1 \%$ level.

Antinutritional factors viz. oxalate and phytin phosphorus content of chikki is presented in the Table 4. The perusal of data showed that oxalate and phytin phosphorus content was increased in the supplemented chikki. Garden cress seeds has sufficient amount of these antinutritional factors, which were responsible for the increase of these factors in the developed product.

Chikki prepared with standard formulation contained $72.9 \pm 0.36 \mathrm{mg}$ per $100 \mathrm{~g}$ oxalic acid which increased to 73.88 $\pm 0.47 \mathrm{mg} / 100 \mathrm{~g}$ in supplemented chikki while, the phytin phosphorus content of control and supplemented chikki was found $284.8 \pm 2.26$ and $286.10 \pm 2.46 \mathrm{mg}$ per $100 \mathrm{~g}$. Ground nuts showed large amount of phytic (572 - $714 \mathrm{mg} / 100 \mathrm{~g}$ ) and oxalic acid (131 mg/100g on wet basis) [21]. Chahal \& Sehgal [16] also reported phytic acid content of ground nut as $547 \mathrm{mg}$ per $100 \mathrm{~g}$. It might be a reason that chikki was found with high oxalic acid and phytin phosphorus content $[22,23]$.

\section{Conclusion}

On the basis of the findings it can be inferred that roasted garden cress seeds supplemented chikki was found richer in proximate, amino acids and fatty acid composition than control chikki. Supplementation of garden cress seeds 
also improved iron, calcium and zinc content of chikki but decreased in vitro digestibility of chikki due to increased content of antinutritional factors present in it. It is suggested that trials should be performed to decrease the antinutritional factors and improve the digestibility of chikki. The product has potential to be fed to poor and malnourished children through various supplementary feeding programmers.

\section{Reference}

1. Gopalan C, Sastri BVR, Balasubramanian SC, Rao BS Narsinga, Deosthale YG, et al. (2011) Nutritive Value of Indian Foods. National Institute of Nutrition, Indian Council of Medical Research, Hyderabad, India.

2. Gokavi SS, Malleshi NG, Guo M (2004) Chemical composition of garden cress (Lepidiumsativum) seeds and its fractions and use of bran as a functional ingredient. Plant Foods Human Nutr 59(3): 105-111.

3. Chetana R, Sunkireddy YR (2011) Preparation and quality evaluation of peanut chikki incorporated with flaxseeds. J Food Sci Technol 48(6): 745-749.

4. Watts BM, Ylimaki GL, Jeffery LE, Elias LG (1989) Basic sensory methods for food evaluation.IDRC-277e, The International Development research Centre, Ottawa, Canada.

5. AOAC (2000) Official methods of analysis. (13 ${ }^{\text {th }}$ edn), Association of Official Analytical Chemists, Washington, USA.

6. Horn MJ, Jones DB, Blum AE (1946) Colorimetric determination of methionine in proteins and foods. J Bio Chem 166(1): 313-320.

7. Liddell HP, Saville B (1959) Colorimetric determination of cysteine. Analyst 84: 188-190.

8. Concon JM (1975) Rapid and simple method for the determination of tryptophan in cereal grains. Anal Biochem 67(1): 206-219.

9. Appleqvist LA (1968) Rapid methods of lipid extraction and fatty acid ester preparation for seed and leaf tissue with special remarks on preventing the accumulation of lipid contaminants. Ark Kenci 28(36) 351-370.

10. Lindsey WL, Norwell MA (1969) A new DPTA- TEA soil test for zinc and iron. Agronomy Abstracts 61: 84.
11. Rao BSN, Prabhavathi T (1978) An in vitro method for predicting the bioavailability of iron from foods. Am J Clin Nutr 31(1): 169-175.

12. Bernfeld F (1954) Amylases $€$ and $\beta$, Methodology of Enzymology. I Acad Press, New York, USA, pp. 149

13. Akeson WR, Stahman MA (1964) A pepsin pancreatin digest index of protein quality evaluation. J Nutr 83: 257-261.

14. Abeza RH, Black JT, Fisher EJ (1968) Oxalates determination. Analytical problems encountered with certain plant species. J Assoc Official Analytical Chemists 51: 963-967.

15. Haug W, Lantzsch HT (1983) Sensitive method for rapid determination of phytate in cereal and cereal products. J Sci Fd Agric 34(12): 14-23.

16. Chahal S, Sehgal S (1996) Development, acceptability and nutritional evaluation of homemade supplements for school children. Nahrung 40(6): 345-347.

17. Byrappa V P, Ramakrishna C, Sunkireddy YR (2014) Processing, physicchemical, sensory and nutritional evaluation of protein, mineral and vitamin enriched peanut chikki - an Indian traditional sweet. J Food Sci Technol 51(1): 158-162.

18. Jain T, Grover K, Kaur G (2016) Effect of Processing on Nutrients and Fatty Acid Composition of Garden Cress (Lepidiumsativum) Seeds. Food Chem 213: 806-812.

19. Kotagi KS, Chimmad B (2011) Little millet (Panicummiliare) flakes: Development, value addition, quality evaluation, consumer acceptability and commercialization. Karnataka J Agric Sci 24: 718.

20. Nathiya M, Vigasini N (2014) Formulation of cereal based nutricookies prepared incorporating garden cress seeds (Lepidiumsativum)- a protein and iron rich snack. Int J Scientific Res 3: 225-226.

21. Chai W, Liebman M (2005) Oxalate content of legumes, nuts, and grainbased flours. J Food Comp Anal 18(7): 723-729.

22. Booth VH (1971) Problems in the determination of FNDB: available lysine. J Sc Food Agric 22: 658.

23. Carpenter KJ (1960) The estimation of available lysine in animal protein foods. Biochem J 77: 604-610.

\section{Your next submission with Juniper Publishers will reach you the below assets}

- Quality Editorial service

- Swift Peer Review

- Reprints availability

- E-prints Service

- Manuscript Podcast for convenient understanding

- Global attainment for your research

- Manuscript accessibility in different formats

( Pdf, E-pub, Full Text, Audio)

- Unceasing customer service

Track the below URL for one-step submission

https://juniperpublishers.com/online-submission.php 